\title{
Mineral enrichment in carrot with different sources and doses of zinc ${ }^{1}$
}

\author{
Jassana Moreira Floriano², Simone Noremberg Kunz ${ }^{2 *}$, Paulo Jorge de Pinho ${ }^{2}$, Carla Tuparai Casabonnet ${ }^{2}$, \\ Edina da Luz Abreu², Eduardo Bohrer Azevedo ${ }^{2}$
}

$10.1590 / 0034-737 X 201865020007$

\begin{abstract}
Zinc ( $\mathrm{Zn}$ ) deficiency in soil and plants and its low nutritional status in the population encourage studies on enrichment of agricultural products. Carrot has potential to enrichment because it is a commonly consumed vegetable. The objective of this study was to evaluate $\mathrm{Zn}$ sources $\left(\mathrm{ZnO}, \mathrm{ZnSO}_{4}\right.$, or $\left.\mathrm{ZnEDTA}\right)$ and doses $\left(0,5,10,20\right.$, and $\left.30 \mathrm{mg} \mathrm{dm}^{-3}\right)$ applied to the soil to increase the concentration of this mineral in the carrot edible part. Zinc sulfate was the most suitable source for this role because it had a higher accumulation with the increase of treatment dose. The best dose was $19.45 \mathrm{mg} \mathrm{dm}^{-}$ ${ }^{3}$ of $\mathrm{ZnSO}_{4}$, which resulted the highest content of $\mathrm{Zn}$ in carrots. Moreover, this treatment increased $\mathrm{Zn}$ in the root by seven times compared with the control. The low production cost of $\mathrm{Zn}$ enrichment of carrots makes them a potential vegetable for the deficiency reduction of this micronutrient in the population nutrition.
\end{abstract}

Keywords: Daucus carota L.; enrichment; nutrient deficiency; micronutrient.

\section{RESUMO}

\section{Enriquecimento mineral de cenouras com diferentes fontes e doses de zinco}

A deficiência de zinco (Zn) no solo e plantas e seu baixo estado nutricional na população estimulam estudos sobre enriquecimento de produtos agrícolas. A cenoura tem potencial para o enriquecimento, pois é um vegetal comumente consumido. O objetivo deste estudo foi avaliar as fontes de $\mathrm{Zn}\left(\mathrm{ZnO}, \mathrm{ZnSO}_{4}\right.$ ou ZnEDTA) e a dose (0, 5, 10, 20 and 30 $\mathrm{mg} \mathrm{dm}{ }^{-3}$ ) aplicadas no solo a fim de aumentar a concentração do mineral na parte comestível da cenoura. $\mathrm{ZnSO}_{4}$ foi mais adequado para esse papel, porque apresentou maior acúmulo com o aumento da dose de tratamento. A melhor dose foi

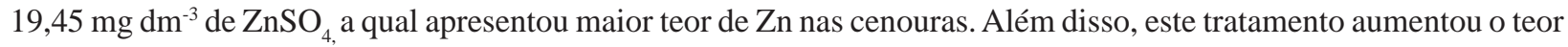
de $\mathrm{Zn}$ na raiz em 7 vezes comparado com o controle. O baixo custo da produção de cenouras enriquecidas com $\mathrm{Zn}$ as torna uma hortaliça potencial para a redução da deficiência deste micronutriente na nutrição populacional.

Palavras-chave: Daucus carota L.; enriquecimento; deficiência nutricional; micronutriente.

\footnotetext{
Submitted on July $31^{s t}, 2017$ and accepted on March $1^{s t}, 2018$

${ }^{1}$ This work is part of the first author's Post-Graduation work.

2'Universidade Federal do Pampa, Itaqui, Rio Grande do Sul, Brazil. jassanamf@hotmail.com; simonsnoremberg@gmail.com; pinhopj@yahoo.com.br; carla.casabonnet@hotmail.com; abreu.edina@gmail.com; ebazevedo@yahoo.com.br

*Corresponding author: simonsnoremberg@gmail.com
} 


\section{INTRODUCTION}

Zinc $(\mathrm{Zn})$ is a trace element that plays an essential role in several organisms, being essential for human and plant growth (Prado, 2008). Its deficiency in soils is a serious global problem; it is estimated that approximately $60 \%$ of the world soil is unsuitable for agriculture due to stress caused by mineral deficiency, unavailability, or toxicity of some nutrients (Pathak et al., 2012). In Brazil, Zn deficiency in soil is the most common among the micronutrients, occurring mainly in sandy soils and Latosols in the Cerrado (Brazilian Savannah) region (Fraige et al., 2007). Liming, a practice to correct the natural acidity of these soils, is often used and further reduces the availability of $\mathrm{Zn}$ to plants, possibly increasing the affinity of this element to specific adsorption sites in the soil (Cunha et al., 2008). Low availability of this metal results in significant reductions in productivity and nutritional quality of food (Henriques et al., 2012).

Tropical soils have high phosphorus (P) fixation, resulting in the need to use corrective phosphate fertilizer, which can induce Zn deficiency (Alloway, 2009). Regions with soil $\mathrm{Zn}$ deficiency are deeply correlated with those that have a high incidence of $\mathrm{Zn}$ deficiency in the population (Henriques et al., 2012). When crop cultures are the main alimentary sources for the local human and animal population, $\mathrm{Zn}$ deficiency in the diet is unavoidable (Erenoglu et al., 2010).

Another important issue is that $\mathrm{Zn}$ is a wide-distribution trace element in the human body, necessary for the activity of more than 200 enzymes involved in the maintenance of important metabolic pathways of the organism (Gibson et al., 2008). It is estimated that $\mathrm{Zn}$ deficiency affects about one third of the world's population (Macêdo et al., 2010); it can be potentially identified as a public health problem in many developing countries. In Brazil, studies from different indicators point to low Zn levels in children (Silva et al., 2006). To control this deficiency, different methods of food fortification can be adopted to ensure availability of essential nutrients, including $\mathrm{Zn}$, commonly used in widely consumed food.

Among the interventions that are being used to solve Zn deficiency in humans, fortification and supplementation are being widely applied in some countries. However, these approaches have a high cost and are not readily available in developing countries. Biofortification with fertilizer is presented as a quick, cost-effective, and useful way in complementary approach to improve nutrient concentrations (Cakmak, 2008). On the other hand, genetic biofortification can present itself as a viable strategy to fight nutritional deficiencies (Rios et al., 2009); however, a multidisciplinary approach is necessary, which includes agronomic knowledge (Moraes et al., 2012).
Carrot (Daucus carota L.) has great potential for mineral enrichment because is a commonly consumed vegetable by the Brazilian population (Brasil, 2009). Therefore, it is important to verify the best ways to get more nutritious cultivars through agronomic practices. Enrichment using micronutrients in common foods access can be an alternative to reduce the growing nutritional problems in the population.

Considering the impact of the lack of $\mathrm{Zn}$ in soil and plants and nutritional status of the population, studies on the agronomic enrichment of food with this element become necessary. In addition, the use of fortified fertilizer with Zn is a recent issue that is rarely studied, mainly in Brazil, despite its importance. Besides, the appropriate use of this micronutrient should be considered because, when applied in high doses, it can cause damage to plants and contamination of soil. Thus, the objective of this study was to evaluate the sources and $\mathrm{Zn}$ doses applied to the soil to increase the concentration of this element in the edible part of carrot, without impairing plant growth and production.

\section{MATERIAL AND METHODS}

\section{Description of the Experimental Area}

The experiment was conducted in the experimental area of the Universidade Federal do Pampa, Campus Itaqui (2907'31" S; 56 33' $11^{\circ}$ " W; altitude $57 \mathrm{~m}$ ) in a greenhouse. The climate is $\mathrm{CFa}$ (temperate subtropical in Köppen classification) and is characterized by having the temperature of the warmest month above $22^{\circ} \mathrm{C}$ and of the coldest month not lower than $3^{\circ} \mathrm{C}$.

\section{Experimental Design and Treatment}

The experimental design was a completely randomized design and treatments were five doses of $\mathrm{Zn}(0,5,10,20$, and $30 \mathrm{mg} \mathrm{dm}^{-3}$ ) and three sources of $\mathrm{Zn}$ (zinc sulfate, zinc oxide, and chelated (EDTA) zinc) with four replicates, applied to the soil. We used 52 vessels with a capacity of $5 \mathrm{~L}$, filled with $3 \mathrm{~kg}$ of sand and $2 \mathrm{~kg}$ vermiculite each. Cultivar Nantes carrots was seeded, with eight seeds distributed in a circular format. After thinning, four plants remained per vessel. The vessels were daily irrigated with deionized water and modified (without zinc) nutrient solution of Hoagland \& Arnold (1950); the ionic strength of the solution started by $10 \%$, being increased with the development of treatments up to the total of $100 \%$. The vessels were identified according to the treatment, dose value, and repetition number.

\section{Evaluation}

On the $34^{\text {th }}$ day after planting and two days before harvest (day 103) the measurement of foliage height was 
carried out. At the end of the experimental period, plants were harvested and the leaf area was separated from the root for determination of fresh and dry matter of both parts, in addition to measurement of root length and diameter. Deformities were also evaluated in the roots and classified according to the Programa Brasileiro para Melhoria dos Padrões Comerciais e Embalagens de Hortigranjeiros (Brazilian Program for the Improvement of Commercial Standards and Horticultural Packaging) (Brasil, 2000).

After these evaluations, samples were prepared for $\mathrm{Zn}$ and $\mathrm{Fe}$ determinations.

\section{Sample Preparation}

The plant tissues were washed in deionized water, followed by weighing and drying in an oven with forced-air circulation at $65^{\circ} \mathrm{C}$ until constant weight. The plant material was ground in a Wiley mill and passed through a sieve of 20 "mesh" (0.841 mm). Dried samples were decomposed by mixture of $\mathrm{HNO}_{3}$ and $\mathrm{H}_{2} \mathrm{O}_{2}$ (3:1) in digester block according to the methodology described by Silva (2009).

\section{Zinc and Iron Determination}

Analysis of $\mathrm{Zn}$ concentration was performed in an atomic absorption spectrophotometer novAA 300, with acetylene/air flame, according to the methodology indicated by the equipment software.

To check one possible interference of $\mathrm{Zn}$ in the iron (Fe) absorption by the plant, the concentrations of $\mathrm{Fe}$ in the sample were determined according to NBR 13934 (ABNT, 1997), with adaptations, in UV-Visible (8453 HPAgilent).

\section{Statistical Analysis}

Statistical analysis was carried out with the program Graph Pad PRISM ${ }^{\circledR} 5.0$ (2007) by one-way ANOVA and Dunnett comparison test when necessary. Results with $\mathrm{p}$ values $<0.05$ were considered significant.

In order to determine the optimal dose for the accumulation of $\mathrm{Zn}$, the segmented regression by brokenline model was performed (Portz et al., 2000; Robbins et $a l ., 2006)$. This model is obtained by the method of least squares and aims to determine the break point, i.e., the point representing the lowest sum of squares. These determinations were performed in Proc NLIN of SAS software.

\section{RESULTS AND DISCUSSION}

\section{Plant Growth and Roots Evaluation}

The measurement of the plant foliage height was carried out to check if there was interference of each treatment on their growth and development. The results performed on the $34^{\text {th }}$ day after planting are shown in Figu- re 1. When comparing the groups of plantas treated with different sources and doses of Zn, ZnEDTA group dose $30 \mathrm{mg} \mathrm{dm}^{-3}$ showed a lower growth of the foliar part of plant compared with the control group in the initial growth. On the other hand, there was no significant difference between groups (data not shown) in relation to the heights measured on the $103^{\text {rd }}$ day. Silva et al. (2014) reported that the source of chelated $\mathrm{Zn}$ reduces the absorption of the elements by the plant. Thus, initially, the use of treatment with ZnEDTA at its highest dosage maintained the nutrients adsorbed in the soil, presenting growth deficit in the plant, which was gradually corrected physiologically during the experiment, being adapted to the conditions to which it was submitted. This may be the explanation for lower leaf growth in ZnEDTA treated plants in the early days, which was no longer significant at the end of the experiment.

After harvesting, weight, length, $\mathrm{Zn}$ content in the edible part, and carrot appearance for purchase intent were evaluated. The replicates that presented carrots with defects are described in Table 1 . Only one replicate of $5 \mathrm{mg} \mathrm{dm}^{-3}$ ZnEDTA dose presented carrots with defects as well as 30 $\mathrm{mg} \mathrm{dm}{ }^{-3} \mathrm{ZnSO} 4$ and $30 \mathrm{mg} \mathrm{dm}^{-3} \mathrm{ZnO}$. On the other hand, for the larger doses of ZnEDTA, more than one vase showed defects, in dose $20 \mathrm{mg} \mathrm{dm}^{-3}$, two replicates, and in $30 \mathrm{mg} \mathrm{dm}^{-}$ ${ }^{3}$, all replicates, sometimes with more than one defect. In Table 1, they are only the treatments that showed defects according to the classification of the Brazilian Program for the Improvement of Standards Commercial and Horticultural Packaging (Brasil, 2000), in which the categorization is done by comparing the product obtained with the established standards. According to the classification norm, the minimum quality standard does not tolerate marketing roots with serious defects, such as deformation, cleavage, rot, wilt, among others. In all treatments in which defects were found, these were classified as 'serious'; the other treatments not presented in Table 1 showed no defects. Therefore, all samples with the dosage $30 \mathrm{mg} \mathrm{dm}^{-3}$ of ZnEDTA were considered unmarketable because all the repetitions of this treatment displayed a serious defect. The treatment with EDTA led to a greater number of groups with defects. Moreover, it was observed that the application of a higher dosage, regardless of source, resulted in an increased frequency of defects.

In relation to root weight, the $20 \mathrm{mg} \mathrm{dm}^{-3} \mathrm{ZnEDTA}$ treatment was the only one that presented lower average weight when compared with the control (Figure 2A). The ZnEDTA treatment also affected root growth, with a length reduction with the use of higher doses (20 and $30 \mathrm{mg} \mathrm{dm}^{-}$ ${ }^{3}$ ) when compared with the control group (Figure $2 \mathrm{~B}$ ). Thus, this treatment showed some degree of toxicity, reducing the size of produced vegetable. According to Sandall (2015), ZnEDTA is more effective when used with dry fertilizer because of its ability to mobility; when used with liquid 
fertilizers, it has the same effectiveness of inorganics; and as main disadvantage, ZnEDTA is more expensive and, therefore, require a greater cost to meet the needs of $\mathrm{Zn}$ in soil. Thus, when evaluating the disadvantages imposed by the application of the doses 20 and $30 \mathrm{mg} \mathrm{dm}^{-3}$ of ZnEDTA source, is possible to conclude that for carrot enrichment, this treatment is not adequate.

\section{Zinc Root Concentration}

As shown in Figure 3, the carrots treated with $\mathrm{ZnO}$ kept increasing $\mathrm{Zn}$ absorption with the increase of metal dose, and up to the maximum dose, it was not possible to observe accumulation stability. In the $\mathrm{ZnSO}_{4}$ treatment, it was observed an absorption peak at $20 \mathrm{mg} \mathrm{dm}^{-3}$ dosage, and afterwards, there was a small drop, which may indicate a certain toxicity at the highest dose. According to Alloway (2009), the reduction in concentration of these elements to reach the point of maximum concentration in the roots may be due to phytotoxicity caused by the high $\mathrm{Zn}$ content in the soil. Chelated Zinc treatment had no increase of $\mathrm{Zn}$

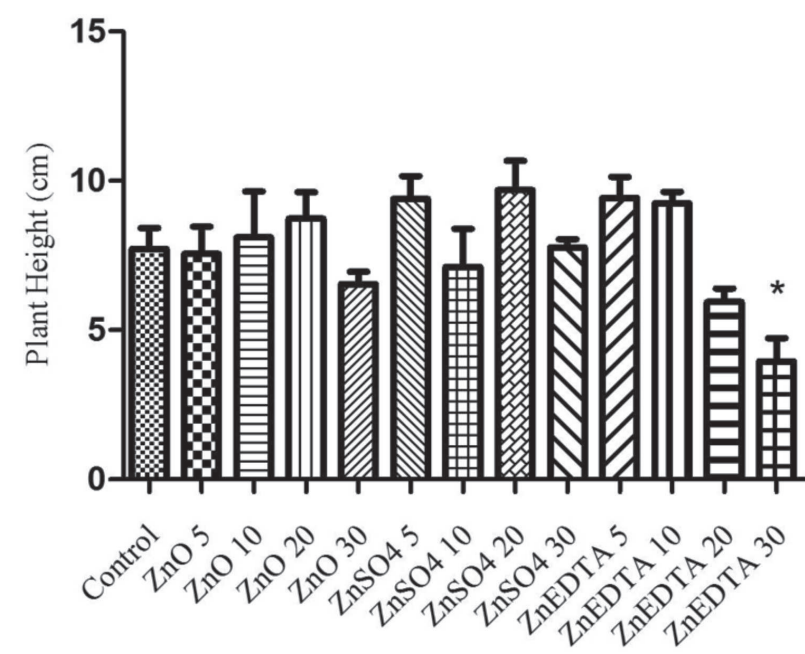

*Different from Control (one-way ANOVA; Dunnett test; $\mathrm{p}<0.05$ ).

Figure 1: Average of plant foliage with different sources and doses of zinc on the 34 th day after planting. accumulation in the root with increment of treatment dosage.

When analyzing the results of the $\mathrm{Zn}$ content in $\mathrm{mg} \mathrm{kg}$ ${ }^{1}$ (Table 2), we verified that the highest contents were found in treatments $\mathrm{ZnO}$ and $30 \mathrm{mg} \mathrm{kg}^{-1} \mathrm{ZnSO}_{4}$; however, these have a high standard deviation evidencing a non-uniformity
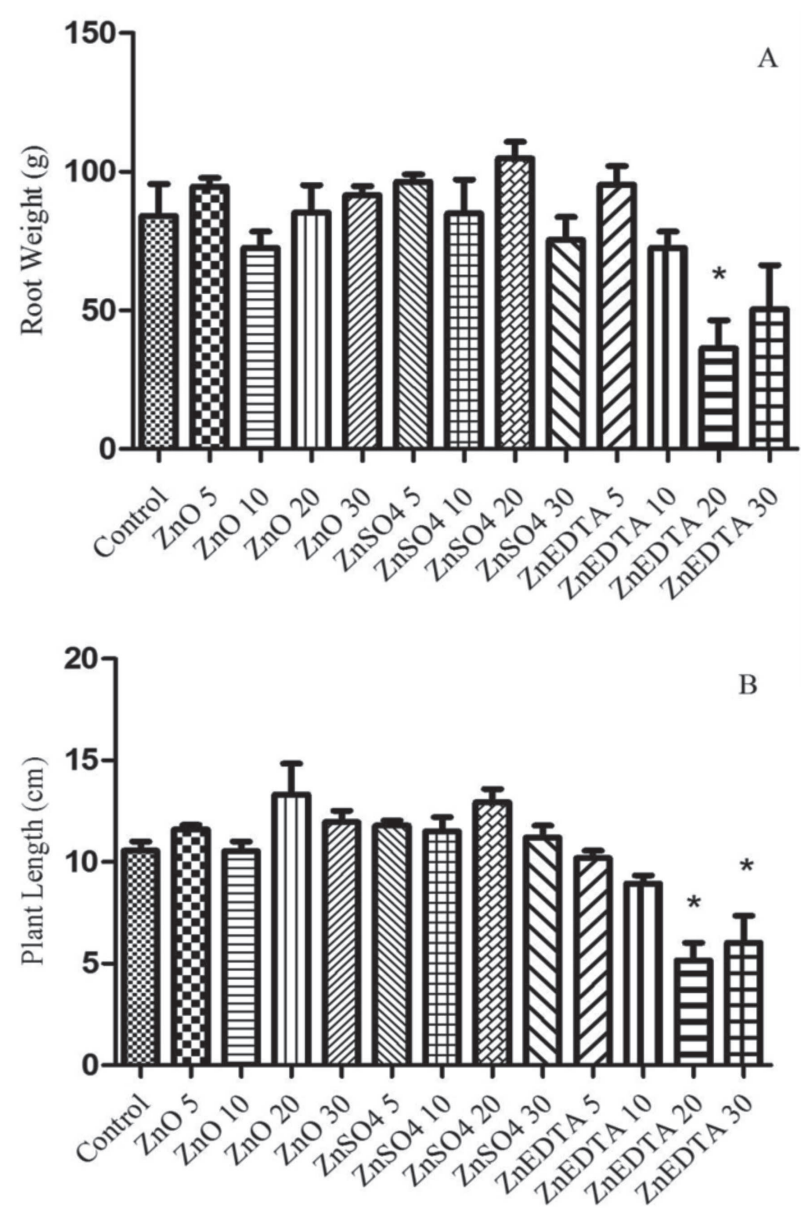

* Different from Control (one-way ANOVA; Dunnett test; $\mathrm{p}<$ $0.05)$.

Figure 2: Root weight in natura (A) and root length (B) with different sources and doses of zinc.

Table 1: Defect type and classification according to the Brazilian Program for the Improvement of Standards Commercial and Horticultural Packaging of roots evaluated. Only treatments with defective carrots are presented

\begin{tabular}{lcc}
\hline Treatment & Defect & Classification \\
\hline ZnEDTA 5* R1** & Deformation & Serious defect \\
ZnEDTA 30* R1** & Crack & Serious defect \\
ZnEDTA 30* R2** & Deformation and Crack & Serious defect \\
ZnEDTA 30* R3** & Deformation and Crack & Serious defect \\
ZnEDTA 30* R4** & Rootless & Serious defect \\
ZnEDTA 20* R1** & Crack & Serious defect \\
ZnEDTA 20* R3** & Crack & Serious defect \\
ZnSO 40* R3** & Crack & Serious defect \\
ZnO 30* R4** & Deformation & Serious defect \\
\hline$*$ Dosage. & &
\end{tabular}




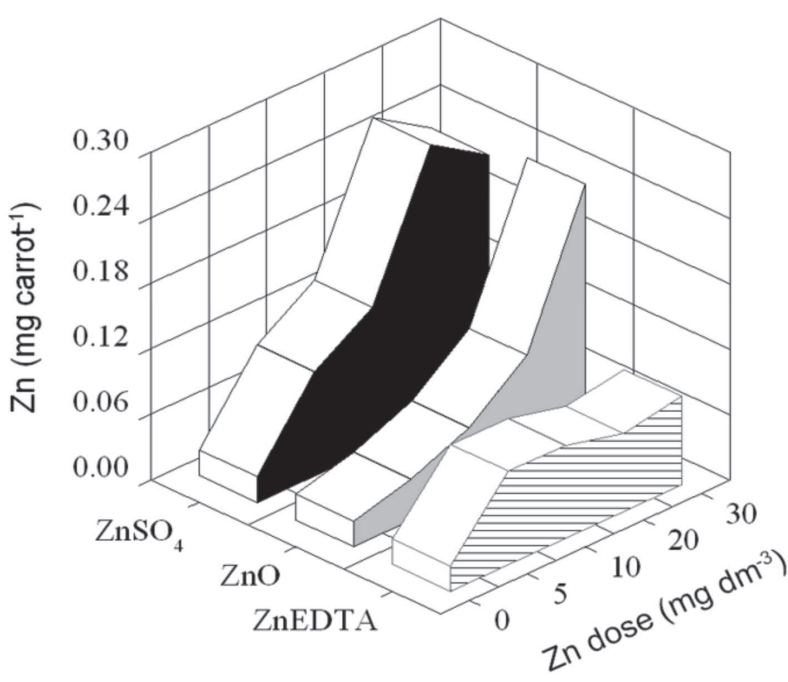

Figure 3: Root $\mathrm{Zn}$ accumulation in relation to dose in treatments, with different sources and doses of zinc.

between the concentrations found in different replicates. The treatment $20 \mathrm{mg} \mathrm{kg}^{-1} \mathrm{ZnSO}_{4}$ does not result in a higher concentration of $\mathrm{Zn}$ but presents a low deviation between the replicates and resulted in a greater accumulation by carrot because they exhibited larger size and better appearance in relation to the other treatments.

About the accumulation of $\mathrm{Zn}$ in the edible part of carrot, it was found that, due to increase in the $\mathrm{Zn}$ content in the soil, the plants generally have higher concentrations of this element, demonstrating that fertilization practice can increase the availability of $\mathrm{Zn}$ to plants, which is potentially absorbed. According to Kabata-Pendias \& Mukherjee (2007), regardless of Zn dose applied in the soil, the highest concentrations are observed mainly in roots, which have low translocation to the shoot. Zinc is minimally translocated to the shoot due to a natural impediment present in its roots
(Andrade et al., 2008), so the carrot has a high potential for enrichment with this element in the edible part, justifying the considerable metal accumulation found in this work.

These results demonstrate that the best treatment for $\mathrm{Zn}$ fortification in carrots is the zinc sulfate source at a dose of $20 \mathrm{mg} \mathrm{dm}^{-3}$ because no deformity was observed in this treatment, and it presented the highest root weight and element accumulation. Zinc oxide also presents an increasing accumulation, but would require a larger dose, which is a disadvantage to this source because it is little soluble. Sandall (2015) mentioned that the $\mathrm{ZnSO}_{4}$ is the $\mathrm{Zn}$ source most used as fertilizer, which, being an inorganic compound relatively soluble in soluble and effective in granular form, should be applied in the areas of soil with low levels of this mineral.

The segmented regression by the broken-line model resulted in break point in dose $19.48 \mathrm{mg} \mathrm{dm}^{-3}$ (Figure 4), indicating that from this, there is no significant difference in $\mathrm{Zn}$ accumulate per carrot and confirming that the dose near $20 \mathrm{mg} \mathrm{dm}^{-3}$ is the ideal.

The Fe concentration found in the samples was not affected. Table 2 shows that there was no significant difference in Fe content from different sources and doses of zinc, which is presented as a positive feature. Since carrot is a food source of $\mathrm{Fe}$, it becomes important to check any reduction of its content. In the study by Lima $e t$ al. (2015), Zn levels found in carrot roots increased linearly, whereas a quadratic response was observed in relation to the Fe content in these plants; thus, it was also confirmed that, with application of increasing doses of $\mathrm{Zn}$ in the soil, there was a reduction of Fe content in the edible parts of carrot. Smical et al. (2008) found that lettuce grown in soil with the addition of $\mathrm{Zn}$ (50 to $300 \mathrm{mg} \mathrm{kg}^{-1}$ ) had higher relative contents of $\mathrm{Fe}$ in the roots, supporting the natural variation of the plant in relation to preferential assignment

Table 2: Average ( \pm s.d.) Fe and $\mathrm{Zn}$ content found in the roots with different sources and doses of zinc $\left(\mathrm{mg} \mathrm{dm}^{-3}\right)(\mathrm{n}=4)$

\begin{tabular}{|c|c|c|}
\hline Treatment & Zn mg kg-1 & Fe mg kg-1 \\
\hline Control & $10.26 \pm 1.74$ & $64.83 \pm 20.61$ \\
\hline $\mathrm{ZnO} 5$ & $11.79 \pm 1.55$ & $44.02 \pm 7.91$ \\
\hline $\mathrm{ZnO} 10$ & $17.32 \pm 1.71 *$ & $66.65 \pm 18.60$ \\
\hline $\mathrm{ZnO} 20$ & $35.81 \pm 12.08 *$ & $65.45 \pm 6.68$ \\
\hline $\mathrm{ZnO} 30$ & $79.09 \pm 21.62 *$ & $62.05 \pm 17.34$ \\
\hline $\mathrm{ZnSO}_{4} 5$ & $30.47 \pm 2.69 *$ & $73.01 \pm 25.11$ \\
\hline $\mathrm{ZnSO}_{4} 10$ & $46.21 \pm 7.60 *$ & $70.16 \pm 21.34$ \\
\hline $\mathrm{ZnSO}_{4} 20$ & $72.31 \pm 8.45^{*}$ & $64.26 \pm 14.88$ \\
\hline $\mathrm{ZnSO}_{4} 30$ & $88.74 \pm 19.20 *$ & $60.35 \pm 4.06$ \\
\hline ZnEDTA 5 & $26.30 \pm 2.09 *$ & $66.92 \pm 6.87$ \\
\hline ZnEDTA 10 & $34.66 \pm 6.39 *$ & $52.73 \pm 6.52$ \\
\hline ZnEDTA 20 & $48.34 \pm 17.93 *$ & $61.72 \pm 15.79$ \\
\hline ZnEDTA 30 & $56.68 \pm 14.19 *$ & $69.15 \pm 7.20$ \\
\hline
\end{tabular}

$*$ Different from control (one-way ANOVA; Dunnett test; $\mathrm{p}<0.05$ ). 
of micronutrients to the roots, differing from that found in this study with carrots.

Zinc and Fe content found in carrot samples of this study showed higher values when compared with the levels of the same vegetable expressed in the Brazilian Table of Food Composition (TACO) $\left(2 \mathrm{mg} \mathrm{kg}^{-1}\right.$ of $\mathrm{Zn}$ and $1 \mathrm{mg} \mathrm{kg}^{-1}$ of Fe) (NEPA, 2011). This difference can be explained by several factors such as the variety used is not specified in TACO Table, besides the experimental design. According to Andrade (2010) and Zapelini \& Zapelini (2007), the trials in which the researcher maintains the phenomena in control conditions and reduces external influences, as occurs in greenhouse and in experiments in vessels, in scientific terms, is the most accurate design. While the field research is subjected to the influence of several variables, since it is applied in natural settings, research in the greenhouse, the control of variables allows the achievement of results under the influence of certain variable analyzed separately by controlled conditions (Couto et al., 2011) so the trend of nutrient accumulation in greenhouse samples is more comprehensible.

Comparing the treatments studied, $\mathrm{ZnSO}_{4}$ has been proved to be the most suitable for enrichment for having a greater accumulation of $\mathrm{Zn}$ with increasing doses. The best dose was $19.45 \mathrm{mg} \mathrm{dm}^{-3}$ of $\mathrm{ZnSO}_{4}$ as it demonstrated higher content depending on the carrot size. Silva et al. (2014) verified in the foliar analysis that the absorption by the plants was differentiated and, also observed that the sulfated source obtained better availability of the nutrient for the plants than that chelated in the bean culture.

Providing $\mathrm{Zn}$ for plant through the application of fortified fertilizer in the soil and/or foliar application seems

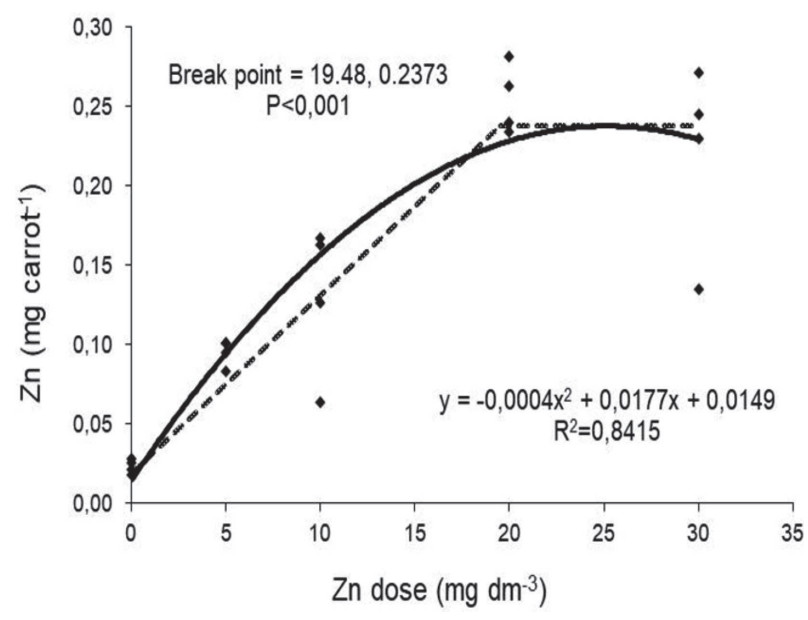

Segmented regression by the broken-line model (—-); tendency line for non-linear regression.

Figure 4: Application of the segmented regression and linear quadratic models to the results of $\mathrm{ZnSO}_{4}$ treatment, fitted to the root $\mathrm{Zn}$ accumulation in per vase response. important to ensure the concentration of this element (Macêdo et al., 2010). The application of fertilizers with Zn has shown promising results, Pascoalino(2014) described an average increase of $\mathrm{Zn}$ concentration in wheat grains of 1.06 times compared with the control. Therefore, carrot has more potential for $\mathrm{Zn}$ biofortification compared with wheat, as this mineral remains more concentrated in the root and has greater difficulty in translocation to aerial parts (Lima et al., 2015).

The introduction of biofortified crops with a higher content of minerals and vitamins complements the existing nutrition interventions and provides a sustainable and inexpensive manner to reach populations with limited access to formal market systems and health (Nutti et al., 2005). In recent years, evaluating among the studied nutrients, the best responses have been obtained with the application of $\mathrm{Zn}$ because it is possible to select efficient plants for greater element accumulation and, also responsive to the addition of this micronutrient by the fertilization (Moraes et al., 2009; White \& Bloadley, 2005). Yilmaz et al. (1997) and Cakmak et al. (2010) evaluated Zn application methods and demonstrated that the application of $\mathrm{Zn}$ doses in the soil improved productivity and $\mathrm{Zn}$ content in wheat grain.

With enrichment using the treatment with best results for plant development $\left(20 \mathrm{mg} \mathrm{dm}^{-3} \mathrm{ZnSO}_{4}\right)$, the $\mathrm{Zn}$ concentration in the root increased by seven times compared with the control (Table 2). According to Institute of Medicine (2001), $\mathrm{Zn}$ recommendation for healthy adults is $8 \mathrm{mg} \mathrm{day}^{-1}$ for women and $11 \mathrm{mg} \mathrm{day}^{-1}$ for men. Thus, the consumption of fortified $100 \mathrm{~g}^{\text {Carrot }}\left(72.31 \mathrm{mg} \mathrm{kg}^{-1}\right)$ would easily reach this recommendation and reduce considerably the potential for this micronutrient deficiency in the population since it corresponds to substantially all the $\mathrm{Zn}$ required in daily intake.

\section{CONCLUSION}

In this study, it was possible to identify the source that seems promising for $\mathrm{Zn}$ enrichment in carrots.

Comparing the sulfate, oxide, and complex (EDTA) sources, the $19.45 \mathrm{mg} \mathrm{dm}^{-3}$ zinc sulfate dose increased vegetable growth and no defect that impairs marketing was detected.

\section{ACKNOWLEDGEMENT}

The authors express their grateful thanks to UNIPAMPA for support.

\section{REFERENCES}

ABNT - Associação Brasileira de Normas Técnicas (1997) Água Determinação de ferro - Método colorimétrico da ortofenantrolina, NBR 13934. Rio de Janeiro, ABNT. 3p. 
Alloway BJ (2009) Soil factors associated with zinc deficiency in crops and humans. Environmental Geochemistry and Health, 31:537-548.

Andrade AFM, Amaral SNMB, Magalhães MOL, Nascimento VS \& Mazur N (2008) Zinco, chumbo e cádmio em plantas de arroz (Oryza sativa L.) cultivadas em solo após adição de resíduo siderúrgico. Ciência Rural, 38:1877-1885.

Andrade MM (2010) Introdução à metodologia do trabalho científico: elaboração de trabalhos de graduação. São Paulo, Atlas. $160 \mathrm{p}$.

Brasil (2010) Pesquisa de Orçamentos Familiares 2008-2009: despesas, rendimentos e condições de vida. Rio de Janeiro, IBGE. $215 \mathrm{p}$.

Brasil (2000) Programa brasileiro para a melhoria dos padrões comerciais e embalagens de hortigranjeiros - Classificação de Cenoura. Disponível em: <http://www.hortibrasil.org.br/jnw/ images/ stories/folders/cenoura.pdf.> Acessado em: 06 de abril de 2016.

Cakmak I (2008) Enrichment of cereal grains with zinc: agronomic or genetic biofortification? Plant and Soil, 302:01-17.

Cakmak I, Pfeiffer WH \& Mcclafferty B (2010) Biofortification of durum wheat with zinc and iron. Cereal Chemistry Journal, 87:10-20.

Couto DR, Scardua MD \& Chimalli T (2011) Pesquisa de Campo Versus Pesquisa de Laboratório. Jerônimo Monteiro, UFES. 19p.

Cunha KPV, Nascimento CWA, Pimentel RMM, Accioly AMA \& Silva AJ (2008) Disponibilidade, acúmulo e toxidez de cádmio e zinco em milho cultivado em solo contaminado. Revista Brasileira de Ciência do Solo, 32:1319-1328.

Institute of Medicine (2001) Dietary Reference Intakes: Dietary reference intakes for vitamin $\mathrm{A}$, vitamin $\mathrm{K}$, arsenic, boron, chromiun, copper, iodine, iron, manganese, molybdnum, nickel, silicon, vanadium, and zinc. Washington, The National Academy Press. 489p.

Erenoglu E, Kutman UB, Ceylan Y, Yildiz B \& Cakmak I (2010) Improved nitrogen nutrition enhances root uptake, root-toshoot translocation and remobilization of zinc $\left({ }^{65} \mathrm{Zn}\right)$ in wheat. New Phytologist, 189:438-448.

Fraige K, Crespilho FN \& Rezende MOO (2007) Determinação de zinco em solo utilizando colorimetria. Química Nova, 30:588591.

Gibson RS, Hess SY, Hotz C \& Brown KH (2008) Indicators of zinc status at the population level: A review of the evidence. British Journal of Nutrition, 99:14-23.

Henriques AR, Chalfun-Junior \& Aarts M (2012) Strategies to increase zinc deficiency tolerance and homeostasis in plants. Brazilian Journal of Plant Physiology, 24:3-8.

Hoagland DR \& Arnon DI (1950) The water culture method for growing plants without soil. Berkeley, California Agricultural Experiment Station. 32p. (Circular, 347).

Kabata-Pendias A \& Mukherjee AB (2007) Trace Elements of Group 12 (Previously Group IIb). In: Kabata-Pendias A \& Mukherjee AB (Eds.) Trace Elements from Soil to Human. New York, Springer. 283-292p.

Lima FS, Nascimento CWA \& Sousa CS (2015) Zinc fertilization as an alternative to increase the concentration of micronutrients in edible parts of vegetables. Revista Brasileira de Ciências Agrárias, 10:403-408

Macêdo EMC, Amorim MAF, Silva ACS \& Castro CMMB (2010) Efeitos da deficiência de cobre, zinco e magnésio sobre o sistema imune de crianças com desnutrição grave. Revista Paulista de Pediatria, 28:329-336.
Moraes MF, Nutti MR, Watanabe E \& Carvalho JLV (2009) Práticas agronômicas para aumentar o fornecimento de nutrientes e vitaminas nos produtos agrícolas alimentares. In: I Simpósio Brasileiro de Apropecuária Sustentável, Viçosa. Anais, UFV. p. 299-312.

Moraes MF, Pascoalino JAL, Alves SJF, Nutti MR \& Carvalho JLV (2012) Biofortificação alternativa à segurança nutricional. Informações Agronômicas, 140:09-15.

NEPA - Núcleo de Estudos e Pesquisas em Alimentação (2011) Tabela Brasileira de Composição de Alimentos - TACO. São Paulo, UNICAMP. 2p.

Nutti MR, Carvalho JLV \& Watanabe E (2005) A biofortificação como ferramenta para combate a deficiências em micronutrientes. In: Silva CR, Figueiredo BR, Capitani EM \& Cunha FG (Eds.) Geologia médica no Brasil: efeitos dos materiais e fatores geológicos na saúde humana, animal e meio ambiente. Rio de Janeiro, CPRM. p.43-47.

Pascoalino JAL (2014) Estratégias de Adubação com Zinco para Biofortificação Agronômica do Trigo. Curitiba, UFPR. 64p.

Pathak GC, Gupta B \& Pendey N (2012) Improving reproductive efficiency of chickpea by foliar application of zinc. Brazilian Journal of Plant Physiology, 24:173-180.

Portz L, Dias CTS \& Cyrino JEP (2000) A broken-line model to fit fish nutrition requirements. Scientia Agricola, 57:601-607.

Prado RM (2008) Nutrição de Plantas. São Paulo, UNESP. 408p.

Rios AS, Alves KR, Costa NMB \& Martino HSD (2009) Review: Biofortificação: culturas enriquecidas com micronutrientes pelo melhoramento genético. Revista Ceres, 56:713-718.

Robbins KR, Saxton AM \& Southern LL (2006) Estimation of nutrient requirements using broken-line regression analysis. Journal of Animal Science, 84:E155-E165.

Sandall L (2015) Soils - Characteristics of Fertilizer Materials. Plant \& Soil Sciences eLibrary, 8:7-8.

Silva AA, Couto Junior PA, Lana AMQ \& Lana RMQ (2014) Teores de micronutrientes no solo e foliar com aplicação de fontes quelatadas e sulfatadas em feijão. Revista Engenharia Agrícola, 34:28-37.

Silva AP, Vitolo MR, Zara LF \& Castro CF (2006) Effects of zinc supplementation on 1-to-5-year old children. Jornal de Pediatria, 82:227-231.

Silva FC (2009) Manual de análises químicas de solos, planta e fertilizantes. Boletim Técnico do Centro de Tecnologia Agrícola e Alimentar. 2a ed. Brasília, Embrapa. 624p.

Smical AI, Hotea V, Oros V, Juhasz J \& Pop E (2008) Studies on transfer and bioaccumulation of heavy metals from soil into lettuce. Environmental Engineering and Management Journal, 7:609-615.

White PJ \& Broadley MR (2005) Biofortifying crops with essential mineral elements. Trends in Plant Science, 10:586-593.

Yilmaz A, Ekiz H, Torun B, Gultekin I, Karanlik S, Bagci SA \& Cakmak I (1997) Effect of different zinc application methods on grain yield and zinc concentration in wheat grown on zincdeficient alcareous soils in Central Anatolia. Journal of Plant Nutrition, 20:461-471.

Zapelini MB \& Zapelini SMKC (2007) Metodologia Científica e da Pesquisa. Florianópolis, FEAN. 200p.

Rev. Ceres, Viçosa, v. 65, n.2, p. 158-164, mar/abr, 2018 